\title{
Gastric diverticulum a rare endoscopic finding
}

\author{
Firdoos Farooq Hajini, Musharraf Husain, Ashraf Bhat, Syed Ishtiyaq Bukhari
}

Department of Surgery, HIMSR, New Delhi, India

\section{Correspondence to Dr Musharraf Husain, drmhusain1@gmail.com}

Accepted 11 March 2014

\section{-}

To cite: Hajini $F F$, Husain M, Bhat A, et al. BMJ Case Rep Published online: [please include Day Month Year] doi:10.1136/ bcr-2013-202887

\section{DESCRIPTION}

A 62-year-old male patient presented to the outpatient department with symptoms of recurrent dyspepsia and pain in the upper abdomen for the past 3 years, for which he was on erratic treatment. There was no history suggestive of chronic cough, peptic ulcer disease or reflux esophagitis. There was no history of Helicobacter pylori eradication therapy or upper abdominal surgery. Gastroscopy showed a wide-mouthed diverticulum of the size of $2 \times 3 \mathrm{~cm}$ in the fundus of the stomach with features of pangastritis (figures 1 and 2). No further investigations were carried out and the patient was put on a proton-pump inhibitor as rapid urease test was negative.

Gastric diverticulum, a rare form of diverticular disease, is an outpouching of the gastric wall. The incidence of gastric diverticula observed by upper gastrointestinal contrast study is $0.04 \%$, however it is $0.02 \%$ in autopsy studies. ${ }^{12}$ It is equally distributed between men and women. It usually presents in the fifth and sixth decade of life. Gastric diverticulum has also been seen in newborns, usually associated with pyloric or duodenal obstruction. ${ }^{3}$ Gastric diverticulum can be congenital, which are true diverticula or acquired which are false diverticula. It can remain asymptomatic or can present with symptoms such as upper abdominal pain, dyspepsia, weight loss, anaemia, reflux or even bleeding and perforation. The patient should be put on symptomatic treatment and surgical intervention is required only when the symptoms do not respond to medical management or if the diverticulum is large. Diverticulectomy is the best surgical management, though invagination of the diverticulum is also an

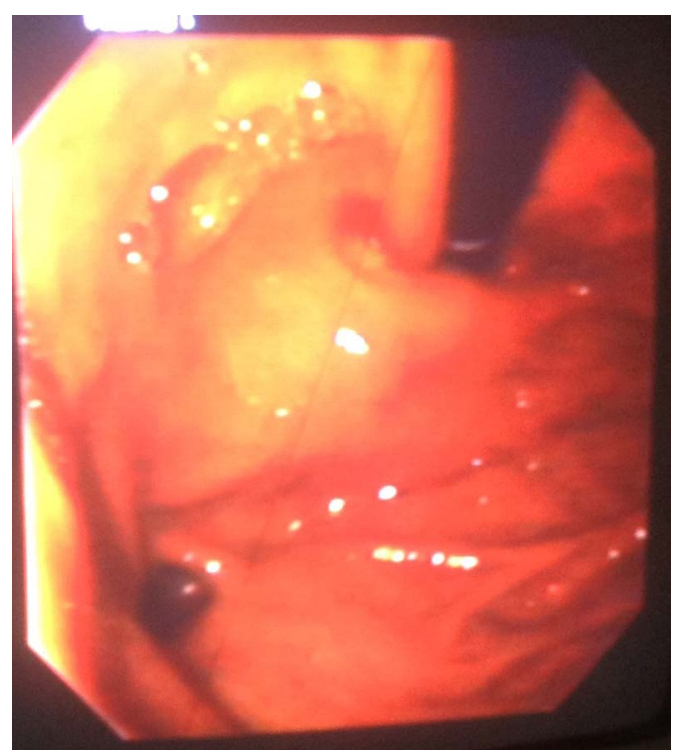

Figure 1 Gastric diverticulum on gastroscopy during retroversion.

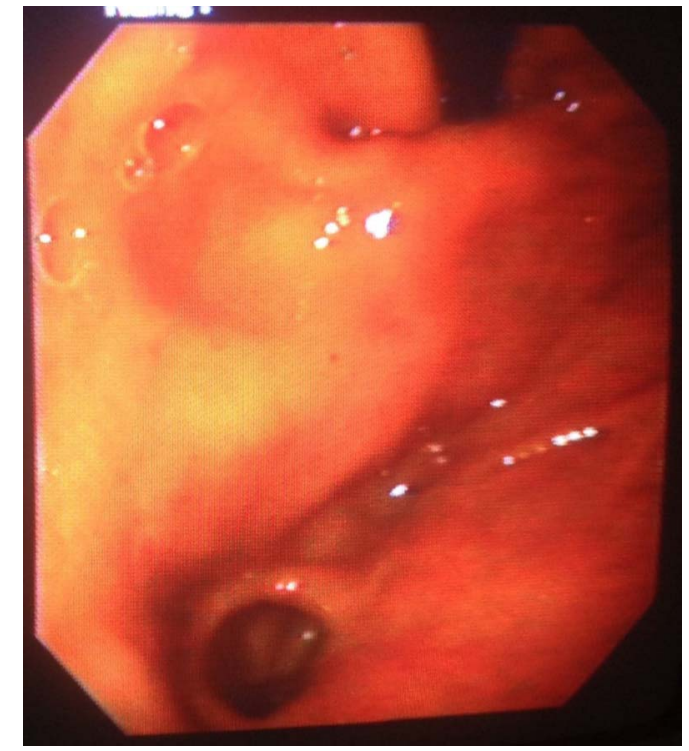

Figure 2 Gastric diverticulum at fundus on gastroscopy during retroversion.

option. Nowadays, these procedures are being done through laparoscopic or transthoracic approach. ${ }^{3}$

\section{Learning points}

- A high index of suspicion should be kept in mind in patients with longstanding history of vague upper abdominal pain and dyspepsia, which do not subside with proton-pump inhibitors.

- Because of the rarity of the disease, gastric diverticulum is liable to cause confusion in diagnosis as they can also be missed even in gastroscopy.

- Contrast study with barium is the best method for the diagnosis if the neck is narrow.

Acknowledgements The authors would like to thank Sana Khan medical student.

Contributors $\mathrm{FFH}$ and $\mathrm{MH}$ were responsible for the drafting of the article. $\mathrm{MH}$ and $\mathrm{AB}$ were responsible for the literature search. SIB provided the photo and performed the proof reading of the article.

Competing interests None.

Patient consent Obtained.

Provenance and peer review Not commissioned; externally peer reviewed.

\section{REFERENCES}

1 Palmer Ed. Collective review: gastric diverticula. Int Abstr Surg 1951:92:417-28

2 River A, Stevens G, Kirklin B. Diverticula of stomach. Surg Gynecol Obstet 1935;60:106-13.

3 Rodeberg DA, Zaheer S, Moir CR, et al. Gastric diverticulum: a series of four pediatric patients. J Pediatr Gastroenterol Nutr 2002;24:564-67. 
Copyright 2014 BMJ Publishing Group. All rights reserved. For permission to reuse any of this content visit http://group.bmj.com/group/rights-licensing/permissions.

BMJ Case Report Fellows may re-use this article for personal use and teaching without any further permission.

Become a Fellow of BMJ Case Reports today and you can:

- Submit as many cases as you like

- Enjoy fast sympathetic peer review and rapid publication of accepted articles

- Access all the published articles

- Re-use any of the published material for personal use and teaching without further permission

For information on Institutional Fellowships contact consortiasales@bmjgroup.com

Visit casereports.bmj.com for more articles like this and to become a Fellow 